\title{
Hong Kong Geriatrics Society and Hong Kong Urological Association consensus on personalised management of male lower urinary tract symptoms in the era of multiple co-morbidities and polypharmacy
}

\author{
Peggy SK Chu, Clarence LH Leung, MH Cheung, Sandy WS Woo, TK Lo *, Tony NH Chan, \\ William KK Wong
}

\begin{abstract}
A B S T R A C T
Lower urinary tract symptoms (LUTS) are common complaints of adult men. Benign prostatic hyperplasia $(\mathrm{BPH})$ represents the most common underlying cause. As the incidence of $\mathrm{BPH}$ increases with age, and pharmacological treatment is a major part of the disease's management, the majority of patients with LUTS are managed by primary care practitioners. There are circumstances in which specialist care by urologists or geriatricians is required, such as failure of medical treatment, adverse effects from medical treatment, or complications from $\mathrm{BPH}$. Referral choices can be confusing to patients and even practitioners in different specialties under such circumstances. There is currently no local consensus about the diagnosis, medical management, or referral mechanism of patients with BPH. A workgroup was formed by members of The Hong Kong Geriatrics Society (HKGS) and the Hong Kong Urological Association (HKUA) to review evidence for the diagnosis and medical treatment of LUTS. A consensus was reached by HKGS and HKUA on an
\end{abstract}

\section{Introduction}

In 2019, Hong Kong overtook Japan as the region with the world's longest life expectancy, with the life expectancy of Hong Kong Chinese men at 82.38 years. ${ }^{1}$ Benign prostatic hyperplasia $(\mathrm{BPH})$ is the most common prostate problem for men older than 50 years. The occurrence of lower urinary tract symptoms (LUTS) due to BPH increases with age. A 1984 autopsy study showed that the prevalence of $\mathrm{BPH}$ rose with each decade after age 40, peaking at $88 \%$ in men in their 80 s. $^{2}$ Since the 1980 s, medical therapy has been prescribed for patients with bothersome LUTS that negatively affects their quality of life. Moreover, the number of co-morbid diseases also increases with age. Co-morbidity increases from $10 \%$ at ages up to 19 years to $80 \%$ at ages 80 years and older. ${ }^{3}$ Co-morbidity also leads to polypharmacy and drug-drug interactions, which may result in serious adverse effects.

There is no established local consensus regarding the management of elderly male patients algorithm for the flow of male LUTS care and the use of uroselective alpha blockers, antimuscarinics, beta-3 adrenoceptor agonists, and $5 \alpha$-reductase inhibitors in the primary care setting. This consensus by HKGS and HKUA provides a new management paradigm of male LUTS.

\section{Hong Kong Med J 2021;27:127-39 \\ https://doi.org/10.12809/hkmj209049}

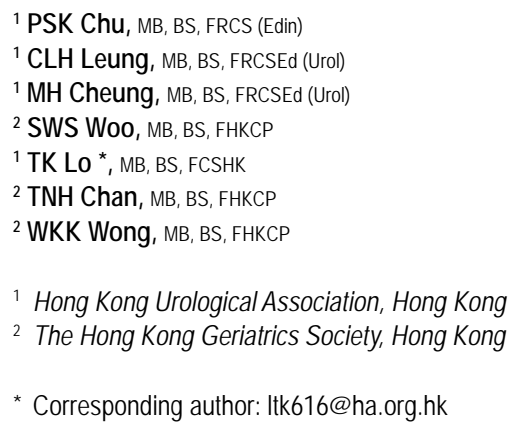

* Corresponding author: Itk616@ha.org.hk

with LUTS. Thus, the Hong Kong Geriatrics Society (HKGS) and the Hong Kong Urological Association (HKUA) formed a working group with the aim of providing insights to clinicians involved in the medical management of male patients with LUTS through a consensus article.

\section{Diagnostic evaluation}

The causes of male LUTS can be multifactorial. Detailed history, appropriate questionnaires, physical examination, and investigation not only help clinicians to reach a diagnosis and identify some alarming conditions (eg, prostate cancer and bladder cancer) but also guide treatment options and give prognostic information for patients' counselling.

\section{History}

It is useful to determine the most predominant and bothersome LUTS to guide their management, eg, voiding symptoms (weak stream, intermittency, 


\section{在多病共存和多重用藥時代下，香港老人科醫學 會與香港泌尿外科學會對下尿路症狀男性患者的 個人化治療的共識}

\author{
朱秀群、梁樂希、張文虹、胡偉珊、盧挺傑、陳毅影、黃國強
}

下尿路症狀是成年男性的常見症狀, 而良性前列腺增生是最常見的潛 在原因。良性前列腺增生的發生率會隨年齡增長而上升, 主要以藥物 治療。因此, 大部分下尿路症狀患者可以向初級保健人員尋求治療。 患者在某些情況下, 例如治療失敗、對藥物出現不良反應或良性前列 腺增生引起併發症時, 則需要泌尿科或老年科醫生提供專科護理。在 這種情況下, 轉診與否可能使患者甚或不同專科的醫護人員感到困 惑。目前香港尚未有關於良性前列腺增生患者的診斷、治療或轉診機 制的本地共識。香港老人科醫學會和香港泌尿外科學會的成員組成工 作小組, 審核下尿路症狀的診斷和醫學治療證據。兩會就有關下尿路 症狀男性患者的護理流程, 以及在基層醫療機構中使用尿路選擇性 $\alpha$ 受體阻滯劑、抗毒草鹼藥、 $\beta-3$ 腎上腺素受體激動劑和 $5 \alpha$-還原酶抑 製劑達成共識。這份共識為下尿路症狀男性患者提供新的治療範例

hesitancy, incomplete emptying) and storage symptoms (urgency, frequency, nocturia). The severity of symptoms can be categorised by the International Prostate Symptoms Score as mild (0-7), moderate (8-19), or severe (20-35). It is a validated tool for the assessment of symptoms and quality of life in patients with LUTS (online supplementary Appendix) and allows objective monitoring of treatment response.

Focused histories of the presence of neurological diseases, diabetes mellitus, medication, drinking habits, and prior lower urinary tract procedures are useful to identify causes of LUTS other than $\mathrm{BPH}$ (eg, neurogenic bladder, polydipsia, urethral stricture).

Referral to geriatricians should be considered in elderly patients with history of postural hypotension, delirium, dementia, frequent falling, or polypharmacy, as these patients have a higher risk of adverse effects from medical treatment of LUTS, and comprehensive geriatric assessment may be necessary.

Alarming symptoms should raise suspicion of pathologies other than $\mathrm{BPH}$, eg, gross haematuria or unexplained dysuria may imply underlying neoplastic or inflammatory causes, or bedwetting may imply underlying chronic urinary retention with overflow incontinence. Prompt referral to urologists is preferable in the presence of such symptoms.

\section{Physical examination}

Digital rectal examination is used to assess prostate size, consistency, the presence of prostatic nodules, and anal tone. In addition, focused examination of the abdomen, external genitalia, and lower limbs is important. Palpable bladder, phimosis, penile mass, and abnormal neurological signs are important to notice when considering referral to appropriate specialists.

A rough estimation of prostate size by number of finger breaths on digital rectal examination is acceptable and may guide the use of $5 \alpha$-reductase inhibitors (5ARi). Imaging assessment by ultrasound can be considered if more accurate assessment is preferred.

\section{Investigations}

Most patients with LUTS have slow deterioration of symptoms, and very few develop complications over a 5-year period. ${ }^{4}$ In the primary care setting, the aim of initial evaluation is to detect non-BPH causes, and urinalysis should be included. Prostatespecific antigen (PSA) can be measured after proper counselling, and serum creatinine should be checked when renal impairment is suspected. Numerous additional investigations are also possible, such as flow rate measurement, post-void residual urine volume, renal ultrasonography, prostate sizing, or urodynamic study. However, these additional investigations are optional and need not be routinely performed at the initial evaluation, as they are not cost-effective. Selected patients with appropriate indications (eg, LUTS with poor response to medical treatment, presence of alarming symptoms, impaired renal function) benefit the most from these tests, and input from specialists is preferred in these circumstances.

\section{Urinalysis}

Urinalysis (dipstick or sediment count) should be included in the primary evaluation of any patients presenting with LUTS to search for urinary tract infections, microscopic haematuria, and diabetes mellitus. If abnormal findings are detected, further tests are recommended. ${ }^{5}$

\section{Prostate-specific antigen}

One of the differential diagnoses of male LUTS is prostate cancer. Prostate-specific antigen is organspecific but not cancer-specific. There is substantial overlap in values between men with benign and malignant prostate disease. Hence, elevated PSA levels should be interpreted with caution.

For patients with abnormal DRE, checking PSA can increase the detection rate of prostate cancer. However, for patients with normal DRE, PSA should be checked only when the detection of prostate cancer will cause the disease's management to be modified. In general, in patients with life expectancy of $<10$ years or with multiple co-morbidities, checking of PSA to detect prostate cancer might not be beneficial to the patient and should only be performed with special justification after proper counselling. 


\section{Serum creatinine}

Assessment of renal function should be considered in patients with high risk of renal impairment (eg, those with multiple co-morbidities and polypharmacy).

\section{Treatment}

The majority of patients with LUTS have slow progression of symptoms, with fewer than $2 \%$ developing urinary retention and fewer than 10\% requiring BPH surgery over a 5 -year period. ${ }^{4}$ Patients not bothered by their symptoms can be safely managed conservatively with education and lifestyle changes. ${ }^{6}$ Examples of lifestyle changes include reduction of fluid intake before bedtime to lessen nocturia, avoidance of caffeinated beverages or alcohol to reduce frequency and urgency, urethral milking to prevent post-micturition dribbling, and optimising the timing of medication, especially diuretics.

In addition to education and lifestyle changes, medical treatment can be considered for patients with bothersome symptoms. Voiding symptoms can be regarded as the manifestation of underlying bladder outlet obstruction resulting from $\mathrm{BPH}$, which underpins the rationale of using alpha-1 adrenoceptor antagonists ( $\alpha 1$-blockers). Storage symptoms can be attributed to either underlying obstruction-induced change in bladder function or overactive bladder without bladder outlet obstruction. The choice of agent depends on the predominant type of symptoms (ie, voiding vs storage symptoms). For patients with predominant voiding symptoms, the first-line medical treatment is $\alpha 1$-blockers, which have been shown to improve both voiding and storage symptoms. ${ }^{7}$ For patients with predominant storage symptoms or residual storage symptoms after a trial of $\alpha 1$-blockers, antimuscarinics and beta- 3 adrenoceptor agonist ( $\beta 3$ agonist) can be considered. For patients with large prostate (eg, $>40 \mathrm{cc}$ ), $5 \mathrm{ARi}$ can be used to reduce the prostate size, improving symptoms and preventing disease progression in terms of acute urinary retention and future need of BPH surgery. It is important to consider adverse effects before starting medical treatment, especially in older patients with multiple co-morbidities and polypharmacy.

Surgical treatment can be considered for patients who develop BPH complications (eg, urinary retention, bladder stones, obstructive uropathy, recurrent urinary tract infection, haematuria) or symptoms refractory to medical treatment. However, surgery is associated with potential morbidities and mortality, especially in frail geriatric patients.

Frailty is a syndrome characterised by reduced physiological reserve and increased vulnerability to adverse outcomes. Even minor stressor events such as surgery can trigger disproportionate worsening of health status in frail elderly people. The most frequently used model to identify frailty is the phenotype described by Fried et $\mathrm{al}^{8}$ in 2001, which comprises five variables: unintentional weight loss, self-reported exhaustion, low energy expenditure, slow gait speed, and weak grip strength. The definition of polypharmacy has no universally agreed cut-off point with regard to the number of medications. Different researchers have arbitrarily chosen various cut points. In the late 1990's, the United States Centers for Medicare and Medicaid Services implemented a quality indicator measure that targets patients taking nine or more concurrent medications. An alternative definition of polypharmacy is the use of more medications than are medically necessary. ${ }^{9}$

After commencement of medical therapy, apart from the monitoring of treatment response and adverse drug reactions, it is also crucial to review medical conditions and identify the new occurrence of geriatric red flags (eg, frailty, polypharmacy) as patients age. The consensus algorithm on male LUTS care flow in the primary care setting by HKGS and HKUA is outlined in Figure 1.

\section{Alpha-1 adrenoceptor antagonists}

The use of $\alpha 1$-blockers has been shown to be effective at reducing LUTS associated with $\mathrm{BPH}^{5}$ The $\alpha 1$-blockers relax smooth muscle tone at the bladder neck and prostate by blocking the action of endogenously released noradrenaline. ${ }^{10}$ They are usually considered as the first-line therapy for male LUTS because of their good efficacy on symptomatic relief but do not alter the natural progression of the disease.

Currently available $\alpha 1$-blockers include prazosin, terazosin, doxazosin, alfuzosin, tamsulosin and silodosin. They have different uroselectivity, pharmacokinetic properties, and formulations (Table 1). Prazosin is a short-acting drug that requires multiple dosing schedules and was the earliest drug to be used for treatment of $\mathrm{BPH}$. However, the 2003 American Urological Association Guidelines concluded that there was insufficient support for recommending prazosin as a treatment option for LUTS secondary to BPH. ${ }^{11}$ These and the European Association of Urology Guidelines regard prazosin as a nonstandard treatment.

Although different $\alpha 1$-blockers have similar efficacy in improving symptoms and uroflow at appropriate doses, uroselective agents $(\alpha-1 \mathrm{~A}$ blockers) and long-acting preparations appeared to be better tolerated. The differences between the tolerability of various $\alpha 1$-blockers can be explained by the differences in the expression and distribution of receptor subtypes (alpha 1A and 1B) in the body (Fig 2). 


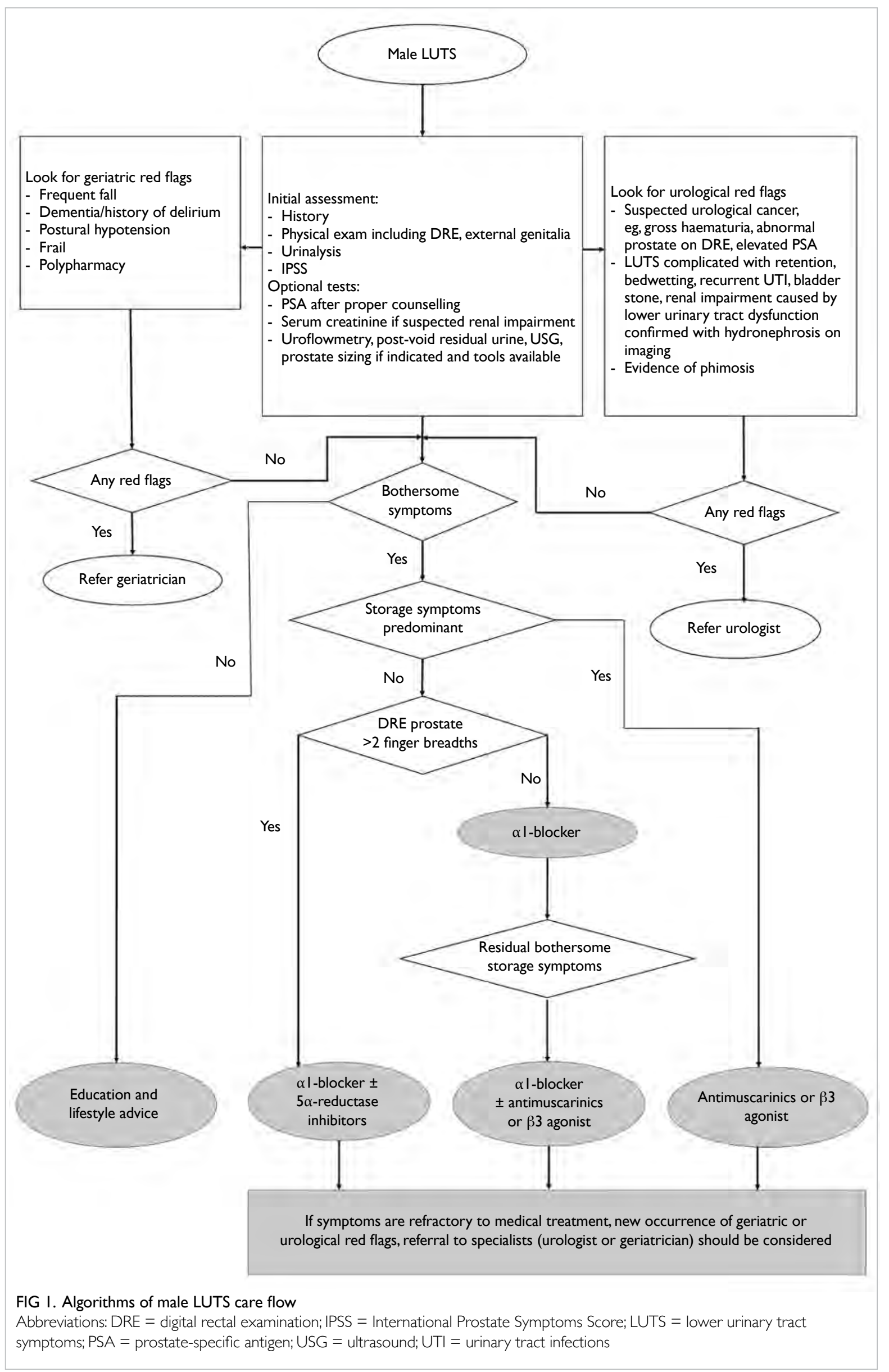


TABLE I. Comparison of currently available alpha I blockers in Hong Kong

\begin{tabular}{|c|c|c|c|c|c|}
\hline & Terazosin & Doxazosin & Alfuzosin & Tamsulosin & Silodosin \\
\hline Dosage form & Tablet & Tablet & Tablet & Tablet & Capsule \\
\hline Selectivity & Non-selective & Non-selective & Non-selective & Uroselective & Uroselective \\
\hline Dosing & $\begin{array}{l}1-10 \mathrm{mg} \text { daily at } \\
\text { bedtime }\end{array}$ & $\begin{array}{l}\text { IR: } 1-8 \text { mg daily } \\
\text { GITS: } 4-8 \text { mg daily }\end{array}$ & XL: 10 mg daily & $\begin{array}{l}\text { D: } 0.2 \mathrm{mg} \text { daily } \\
\text { OCAS: } 0.4 \mathrm{mg} \text { daily }\end{array}$ & $\begin{array}{l}4 \mathrm{mg} \text { bid } / 8 \mathrm{mg} \text { daily } \\
\text { After meal }\end{array}$ \\
\hline Need of titration & Yes & $\begin{array}{l}\text { IR: Yes } \\
\text { GITS: No }\end{array}$ & No & No & No \\
\hline Administration & May be cut or crushed & GITS: Do not crush/cut & Do not crush/cut & OCAS: Do not crush/cut & Capsule can be opened \\
\hline Hepatic impairment* & No adjustment & $\begin{array}{l}\text { Not recommended in } \\
\text { severe impairment }\end{array}$ & $\begin{array}{l}\text { Contra-indicated in } \\
\text { moderate to severe } \\
\text { impairment }\end{array}$ & $\begin{array}{l}\text { No adjustment (no clinical } \\
\text { study on severe patients) }\end{array}$ & $\begin{array}{l}\text { Mild: No adjustment } \\
\text { Moderate: } 4 \text { mg daily } \\
\text { Severe: Contra-indicated }\end{array}$ \\
\hline Renal impairment $†$ & No adjustment & No adjustment & $\begin{array}{l}\text { Caution in severe } \\
\text { impairment }\end{array}$ & $\begin{array}{l}\text { No adjustment (no clinical } \\
\text { study on severe patients) }\end{array}$ & $\begin{array}{l}\text { Mild: No adjustment } \\
\text { Moderate: No adjustment } \\
\text { Severe: Contra-indicated }\end{array}$ \\
\hline
\end{tabular}

Abbreviations: $\mathrm{CrCl}=$ creatinine clearance; $\mathrm{D}=$ disintegrating tablet; $\mathrm{GITS}=$ gastrointestinal therapeutic system; $\mathrm{IR}=\mathrm{immediate}$ release; $\mathrm{OCAS}=$ oral controlled absorption system; $\mathrm{XL}=$ prolonged release

* Hepatic impairment: mild (Child-Pugh class A); moderate (Child-Pugh class B); severe (Child-Pugh class C)

† Renal impairment: mild $(\mathrm{CrCl}>50 \mathrm{~mL} / \mathrm{min})$; moderate $(\mathrm{CrCl} 30-50 \mathrm{~mL} / \mathrm{min})$; severe $(\mathrm{CrCl}<30 \mathrm{~mL} / \mathrm{min})$

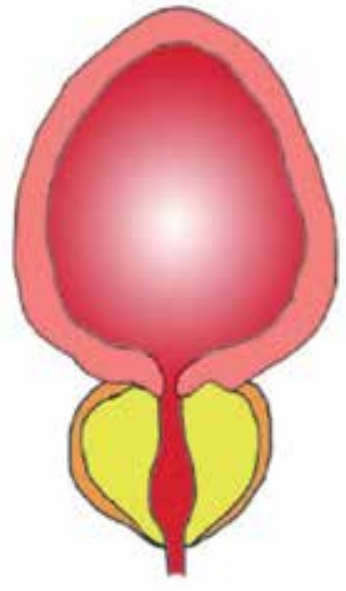

Alpha $1 \mathrm{~A}$ adrenoceptors are the predominant subtype in prostate. Blockage of alpha 1 A adrenoceptors in prostate accounts for the therapeutic effects in treatment of BPH

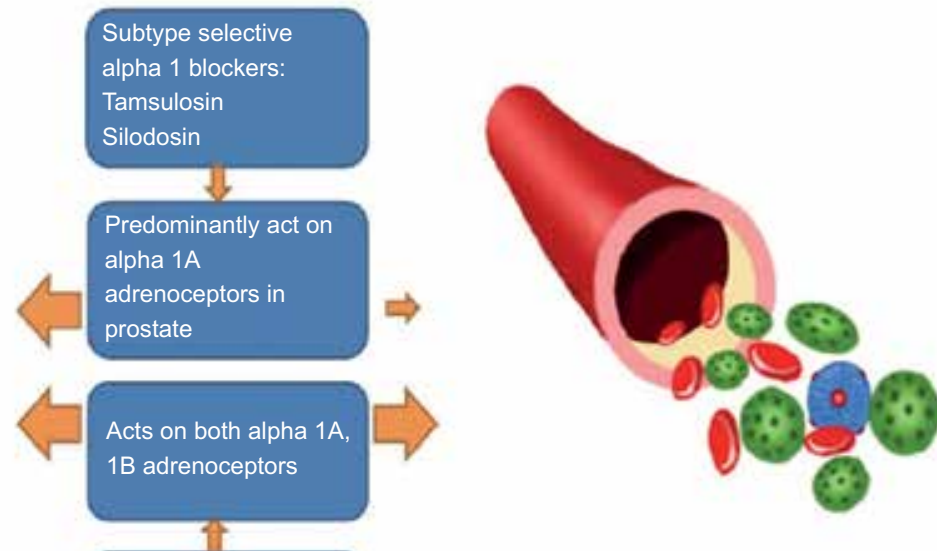

Alpha 1B adrenoceptors are the predominant subtype in vasculature. Blockage of alpha $1 \mathrm{~B}$ adrenoceptors in vasculature accounts for the undesirable adverse effects eg, hypotension

FIG 2. Link between the expression and distribution of alpha-I receptor subtypes and the tolerability of alpha I blockers Abbreviation: $\mathrm{BPH}=$ benign prostatic hyperplasia

Major adverse effects of $\alpha 1$-blocker use heart rate was observed with tamsulosin, whereas no include dizziness, asthenia, postural hypotension, significant change was demonstrated with silodosin and syncope, which can result in falling (odds ratio compared with placebo in a randomised controlled $[\mathrm{OR}]=1.14)$ and fractures $(\mathrm{OR}=1.16)$, especially in trial. ${ }^{15}$ elderly people ${ }^{12}$ the majority of whom cannot tolerate these drugs at the higher adult dose range. Studies have consistently demonstrated that uroselective complications during cataract least effect on blood pressure and the lowest risk of surgery, and it is suggested that ophthalmologists developing vascular-related events. ${ }^{7,13,14}$ However, a be reminded so that they can take precautions. minor but significant change in blood pressure and Sexually active patients should be informed of the 
adverse effect of abnormal ejaculation, which was another adverse reaction more commonly related with tamsulosin $(\mathrm{OR}=8.58)$ and silodosin $(\mathrm{OR}=32.5)$, and patients should be informed of the potential implications. ${ }^{17}$

Patients who are naïve to $\alpha$-blockers may develop postural hypotension, known as the "first dose phenomenon," which is more pronounced with non-selective $\alpha 1$-blockers during the first 8 weeks of treatment. However, it should not be overlooked with uroselective agents, and special precautions should be taken, especially in elderly patients. In addition, swallowing difficulties are not uncommon in elderly patients, in whom modified release preparations are inappropriate.

The pitfalls of prescribing $\alpha 1$-blockers are summarised in Table 2. ${ }^{18}$ Their most troublesome adverse effect is postural hypotension. The situation is even more complicated if the patient has concomitant hypertension or is taking multiple medications with hypotensive effects for various indications. It is estimated that more than $25 \%$ of men aged $>60$ years have concomitant BPH and hypertension, ${ }^{19}$ which poses a significant challenge in the prescription of $\alpha 1$-blockers. Non-selective $\alpha 1$-blockers have been available as antihypertensive agents for over 40 years. They reduce blood pressure by blocking postsynaptic alpha (mainly alpha-1B) receptors, thereby inhibiting noradrenaline release that induces vasoconstriction, resulting in dilatation of arterioles and venules. Among all $\alpha 1$-blockers, prazosin, terazosin, and doxazosin are approved for the management of hypertension, whereas alfuzosin, tamsulosin, and silodosin have minimal effect on blood pressure.
Because certain $\alpha 1$-blockers are approved treatments for hypertension, they are a reasonable choice for treatment of hypertensive men with LUTS. However, with advances in hypertensive treatment over past decades, the role of $\alpha 1$-blockers in this context has changed, especially after the introduction of uroselective agents. A consensus was reached regarding revision of the use of available safety data on $\alpha 1$-blockers in patients with hypertension (Table 3)..$^{20-29}$

\section{Patients with hypertension but not yet taking antihypertensive}

For hypertensive LUTS patients who are not taking any antihypertensives, we do not recommend the use of non-selective $\alpha 1$-blockers for treatment of $\mathrm{BPH}$ and hypertension together (first-line treatment of hypertension). This recommendation is based on the Antihypertensive and LipidLowering Treatment to Prevent Heart Attack Trial Study. ${ }^{20}$ That study showed that compared with chlorthalidone (diuretics), the use of doxazosin is associated with significantly higher risk of stroke, congestive heart failure, peripheral vascular disease, angina, and cardiovascular disease requiring coronary revascularisation. Multiple guidelines (The Eighth Joint National Committee (JNC8) guideline ${ }^{30}$, the European Society of Cardiology/the European Society of Hypertension guideline ${ }^{31}$, the American College of Cardiology/American Heart Association guideline $^{32}$ and Hypertension Canada's 2017 guideline for diagnosis ${ }^{33}$ ) do not recommend $\alpha 1$ blockers as the first-line therapy for hypertension. Therefore, we recommended treating LUTS with

TABLE 2. Pitfalls of prescribing alpha I blockers ${ }^{18}$

\footnotetext{
First-dose phenomenon

To avoid the potential risk of first-dose phenomenon, patients should be aware of hypotensive symptoms within 8 weeks after initiating treatment of $\alpha 1$-blockers. For drugs with a daily dose, it is advisable to start medication at night time. Reducing the initial dosage is also possible

Syncope

Because of the risk of symptomatic postural hypotension, dizziness, or syncope with any $\alpha 1$-blockers, patients should be instructed to avoid situations where injury may result if syncope occurs upon initiation of therapy. In addition, patients should be asked whether they experienced falls while on treatment.

Difficulty swallowing

The $\alpha 1$-blockers in modified release form should be used with special precaution.

Hepatic or renal impairment

Caution and adjustment should be considered for patients with hepatic or renal impairment according to the $\alpha 1$-blockers chosen.

Ejaculatory disorders

Higher incidence of ejaculatory disorders has been reported with uroselective $\alpha 1$-blockers. Patients should be reminded of the issue if planning to have children.

Intraoperative floppy iris syndrome

Patient who plan to undergo cataract surgery should inform ophthalmologists about any drug history of $\alpha 1$-blockers.

Abbreviation: $\alpha$ |-blockers = alpha | blockers
} 
TABLE 3. Recommendations on concomitant use of alpha I blockers with antihypertensive agents (panel's expert opinion) ${ }^{20-29}$

\begin{tabular}{|c|c|c|}
\hline & Hypertensive & Normotensive \\
\hline \multirow[t]{3}{*}{$\begin{array}{l}\text { Not taking } \\
\text { antihypertensive agents }\end{array}$} & $\begin{array}{l}\text { Patients with hypertension but not yet taking } \\
\text { antihypertensive: }\end{array}$ & $\begin{array}{l}\text { Patients with normal blood pressure and not } \\
\text { taking antihypertensive: }\end{array}$ \\
\hline & $\begin{array}{l}\text { Antihypertensive should be initiated to treat } \\
\text { hypertension, whereas uroselective } \alpha 1 \text {-blockers } \\
\text { should be used to treat BPH. }\end{array}$ & $\begin{array}{l}\text { Both uroselective and non-selective } \alpha 1 \text {-blockers } \\
\text { are reasonable options }{ }^{21,22}\end{array}$ \\
\hline & $\begin{array}{l}\text { Non-selective } \alpha 1 \text {-blockers should NOT be used } \\
\text { as the first-line medication for hypertension and } \\
\text { BPH20 }\end{array}$ & \\
\hline \multirow[t]{2}{*}{$\begin{array}{l}\text { Taking antihypertensive } \\
\text { agents }\end{array}$} & $\begin{array}{l}\text { Patients with hypertension but suboptimally } \\
\text { controlled with antihypertensive: }\end{array}$ & $\begin{array}{l}\text { Patients with hypertension and optimally } \\
\text { controlled with antihypertensive: }\end{array}$ \\
\hline & $\begin{array}{l}\text { Adjust antihypertensive agent(s) for blood } \\
\text { pressure control and start uroselective } \alpha 1 \text { - } \\
\text { blockers for treatment of BPH, or continue } \\
\text { current antihypertensive agent(s) and add non- } \\
\text { selective } \alpha 1 \text {-blockers }{ }^{23-26}\end{array}$ & $\begin{array}{l}\text { Uroselective } \alpha 1 \text {-blockers are preferable over } \\
\text { non-selective } \alpha 1 \text {-blockers }\end{array}$ \\
\hline
\end{tabular}

Abbreviations: $\alpha$ |-blockers = alpha I blockers; $\mathrm{BPH}=$ benign prostatic hyperplasia

uroselective agents, and hypertension should be treated with another class of antihypertensives according to existing hypertension guidelines.

\section{Patients with hypertension that is suboptimally controlled with antihypertensive}

For hypertensive LUTS patients who have suboptimal blood pressure control but are taking antihypertensive treatment, the addition of nonselective $\alpha 1$-blockers (doxazosin gastrointestinal therapeutic system [GITS] and terazosin) for treatment of hypertension as second- or third-line agents seems to be a reasonable option for achieving optimal blood pressure control. ${ }^{23-26}$ However, postural hypotension is a significant concern in the treatment group. Therefore, although non-selective $\alpha 1$-blockers are effective at reducing blood pressure as add-on therapy, the risks and benefits of this approach should be balanced and individualised. This is the case especially when other classes of antihypertensives may have additional benefits in certain patients in whom treatment of LUTS with uroselective agents and hypertension separately with another class of antihypertensive agents might be advisable.

\section{Patients with normal blood pressure and not taking antihypertensive}

Among normotensive male patients aged $>40$ years with LUTS who were not taking antihypertensives, a multicentre study showed that doxazosin GITS improved the International Prostate Symptoms Score and the Quality of Life index with minimal effect on blood pressure. ${ }^{21}$ Another review of a1-blockers' effects on blood pressure showed no significant changes in blood pressure in normotensive patients irrespective of the type of a1-blockers used (tamsulosin, alfuzosin, doxazosin GITS, or terazosin). ${ }^{22}$ Therefore, it is reasonable to consider either non-selective or uroselective $\alpha 1$ blockers in this group.

\section{Patients with hypertension that is optimally controlled with antihypertensive}

The safety data on non-selective $\alpha 1$-blockers in normotensive LUTS patients who are taking antihypertensives with optimal blood pressure control are largely based on post-hoc analysis of randomised controlled trials assessing standard versus intensive blood pressure control, which involves non-selective $\alpha 1$-blockers as third- or fourth-line antihypertensives. In the Action to Control Cardiovascular Risk in Diabetes trial, which involved 10251 high-risk participants with type 2 diabetes mellitus at 77 centres, nonselective $\alpha 1$-blockers were significantly associated with postural hypotension, which was associated with higher mortality and rates of heart failure and hospitalisation. ${ }^{27}$ Another European study, the Systolic Blood Pressure Intervention trial, which involved 9361 patients with increased cardiovascular risk but without diabetes, found that non-selective $\alpha 1$-blockers are associated with higher risk of syncope and falling, although no significant hypotensive events were demonstrated..$^{28}$ Therefore, we recommend the use of uroselective agents for management of LUTS in this group of patients.

Apart from the risk of postural hypotension, 
the selection between non-selective and uroselective agents should also be based on other factors, including the risk of falling, polypharmacy, comorbidities, and specific situations where the use of uroselective agents is advisable (Table 4).

Nevertheless, $\alpha 1$-blockers are effective in relieving LUTS and improving quality of life for patients with $\mathrm{BPH}$. However, treatment decisions should be individualised and based on comprehensive assessment of patients with different needs, especially in frail elderly patients, as they tend to have accumulated co-morbidities, disabilities, and polypharmacy that often interact with each other.

\section{Antimuscarinics}

Antimuscarinics are commonly used as pharmacological treatments for overactive bladder. This class of drug can also be used in predominant or mixed storage LUTS. These drugs increase bladder capacity and reduce urgency by blockading the muscarinic receptor during bladder storage. ${ }^{34}$ Antimuscarinics have shown a modest benefit over placebo in reducing urgency incontinence in women. ${ }^{35,36}$ The efficacy of all the antimuscarinics is similar. ${ }^{37}$ However, there is lack of head-tohead comparison, and not all antimuscarinics have been tested in elderly men. These drugs often require higher doses to achieve the optimal effects, and we recommend starting with the lowest dose and titrating up as needed if the patient has insufficient response and minimal adverse effects. Antimuscarinics should be avoided if the patient has clinically palpable bladder. These drugs can be associated with increased post-void residual urine volume after therapy, but acute retention is rare. ${ }^{5}$ Follow-up is recommended at 4 to 6 weeks to assess therapeutic response and determine whether a change in medication is necessary. Men should be advised to discontinue medication if they develop voiding difficulty, urinary infection, or worsening
LUTS after initiation of therapy.

All antimuscarinics exert peripheral anticholinergic effects that may limit drug tolerability and dose escalation. ${ }^{35}$ Common adverse events include dry mouth (up to $16 \%$ ), constipation (up to $4 \%$ ), dizziness (up to 5\%), micturition difficulty (up to $2 \%$ ), blurred vision for near objects, tachycardia, drowsiness, and worsened cognitive function. ${ }^{5} \mathrm{Up}$ to two-thirds of patients discontinue these medications beyond 1 year. ${ }^{38}$ Constipation and compensatory fluid intake for dry mouth may exacerbate urinary incontinence. Patients with dementia are more vulnerabletotheadverse effectsofantimuscarinics..$^{39,40}$ Antimuscarinics should be avoided in patients with uncontrolled tachyarrhythmia, myasthenia gravis, and narrow angle-closure glaucoma. The adverse effects of antimuscarinics can be explained by the distribution of muscarinic acetylcholine receptor subtypes throughout the body (Fig 3). The differences in tolerability between antimuscarinics can be explained by their differences in selectivity for receptor subtypes and tissue penetration.

Antimuscarinics may have additive adverse effects when combined with other medications that have strong anticholinergic effects. They should be used with caution or preferably avoided if elderly patients are concomitantly taking other medications with high anticholinergic potency, eg, firstgeneration $\mathrm{H} 1$ antihistamines (chlorpheniramine, hydroxyzine, diphenhydramine), anti-Parkinson's drugs (benztropine, trihexyphenidyl), spasmolytics (atropine, hyoscine), anti-emetics (promethazine), muscle relaxants, antipsychotics (chlorpromazine, fluphenazine, trifluoperazine, clozapine), and tricyclic antidepressants (amitriptyline, clomipramine, doxepin, imipramine, nortriptyline) ${ }^{41-43}$

The antimuscarinics registered in Hong Kong include oxybutynin, solifenacin, tolterodine, trospium, darifenacin, and fesoterodine. Solifenacin, darifenacin, and trospium may have less impact on the central nervous system (Table 5).

TABLE 4. Consensus for prescribing uroselective agents (panel's expert opinion)

\begin{tabular}{ll}
\hline Factors to be considered & Situations where uroselective agents should be considered \\
\hline $\begin{array}{l}\text { Risk of postural hypotension } \\
\text { High fall risk }\end{array}$ & $\begin{array}{l}\text { Symptomatic hypotension, postural hypotension, or syncope/near syncope prior to or while } \\
\text { on a non-selective } \alpha \text {-blocker }\end{array}$ \\
$\begin{array}{l}\text { Multiple co-morbidities } \\
\begin{array}{l}\text { Patients with benign prostatic hyperplasia who develop symptomatic hypotension while } \\
\text { taking concomitant treatment of antihypertensive agent and a non-selective } \alpha 1 \text {-blocker } \\
\text { antihypertensive agents/PDE5i } \\
\text { on demand }\end{array}\end{array}$ & $\begin{array}{l}\text { Patients with polypharmacy (multiple co-morbidities) } \\
\text { Patients with conditions that do not allow adequate time for titration with a non-selective }\end{array}$ \\
& Patients who are taking PDE5i on demand (be aware of the potential risk of hypotension) \\
\hline
\end{tabular}

Abbreviation: $\mathrm{PDE} 5 \mathrm{i}=$ phosphodiesterase type 5 inhibitor 
TABLE 5. Dosage, formulation, metabolism, and administration of antimuscarinics

\begin{tabular}{|c|c|c|c|c|}
\hline Medication & Starting dose & Maximum dose & Metabolism & Administration information \\
\hline $\begin{array}{l}\text { Oxybutynin } \\
\text { (5 mg tablet) }\end{array}$ & $\begin{array}{l}5 \text { mg, } 2 \text { or } 3 \text { times } \\
\text { daily }\end{array}$ & $5 \mathrm{mg}, 4$ times daily & $\begin{array}{l}\text { Dizziness and somnolence can occur } \\
\text { Often not tolerated by elderly patients because } \\
\text { of anticholinergic adverse effects (including the } \\
\text { central nervous system) } \\
\text { Reduced dose in older adults } \\
\text { Short duration of effects may be useful when } \\
\text { continence is desired at specific times }\end{array}$ & $\begin{array}{l}\text { Can be crushed } \\
\text { Suitable for tube feeding }\end{array}$ \\
\hline $\begin{array}{l}\text { Tolterodine } \\
\text { ( } 1 \text { and } 2 \text { mg tablets) }\end{array}$ & $1 \mathrm{mg}$, twice daily & 2 mg, twice daily & $\begin{array}{l}\text { Reduced dose for renal and/or hepatic } \\
\text { impairment, not recommended for severe renal } \\
\text { or hepatic impairment } \\
\text { Modestly prolongs QTc interval, caution with } \\
\text { other QTc-prolonging drugs and in patients with } \\
\text { congenital prolonged QT }\end{array}$ & $\begin{array}{l}\text { Can be crushed } \\
\text { Suitable for tube feeding }\end{array}$ \\
\hline $\begin{array}{l}\text { Trospium } \\
\text { ( } 20 \text { mg coated tablet) }\end{array}$ & 20 mg, once daily & 20 mg, twice daily & $\begin{array}{l}\text { Needs to be taken on an empty stomach or } \\
1 \text { hour before a meal } \\
\text { Reduced dose for renal impairment, not } \\
\text { recommended for severe renal impairment } \\
\text { Low risk of drug-drug interactions } \\
\text { Avoid alcohol consumption within } 2 \text { hours }\end{array}$ & Can be crushed \\
\hline $\begin{array}{l}\text { Solifenacin } \\
\text { (5 and } 10 \text { mg tablets) }\end{array}$ & $5 \mathrm{mg}$, once daily & 10 mg, once daily & $\begin{array}{l}\text { Reduced dose for severe renal impairment } \\
\text { or moderate hepatic impairment, not } \\
\text { recommended for severe hepatic impairment } \\
\text { Modestly prolongs QTc interval; caution with } \\
\text { other QTc-prolonging drugs and in patients with } \\
\text { congenital prolonged QT }\end{array}$ & Do not crush \\
\hline $\begin{array}{l}\text { Darifenacin prolonged- } \\
\text { release } \\
\text { ( } 7.5 \text { and } 15 \text { mg tablets) }\end{array}$ & $7.5 \mathrm{mg}$, once daily & 15 mg, once daily & $\begin{array}{l}\text { Metabolised in liver; reduced dose for moderate } \\
\text { hepatic impairment, not recommended for } \\
\text { severe hepatic impairment }\end{array}$ & $\begin{array}{l}\text { Do not crush or chew } \\
\text { Not suitable for tube feeding }\end{array}$ \\
\hline $\begin{array}{l}\text { Fesoterodine } \\
\text { prolonged-release } \\
\text { (4 and } 8 \text { mg tablets) }\end{array}$ & 4 mg, once daily & $8 \mathrm{mg}$, once daily & $\begin{array}{l}\text { Metabolised in liver; reduced dose for severe } \\
\text { renal impairment, not recommended for severe } \\
\text { hepatic impairment }\end{array}$ & Not suitable for tube feeding \\
\hline
\end{tabular}

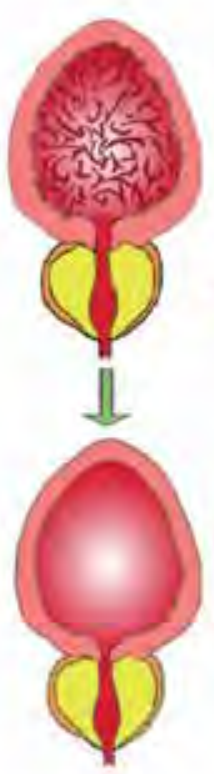

Relaxation of bladder muscle

Bladder: M2 and M3 receptors
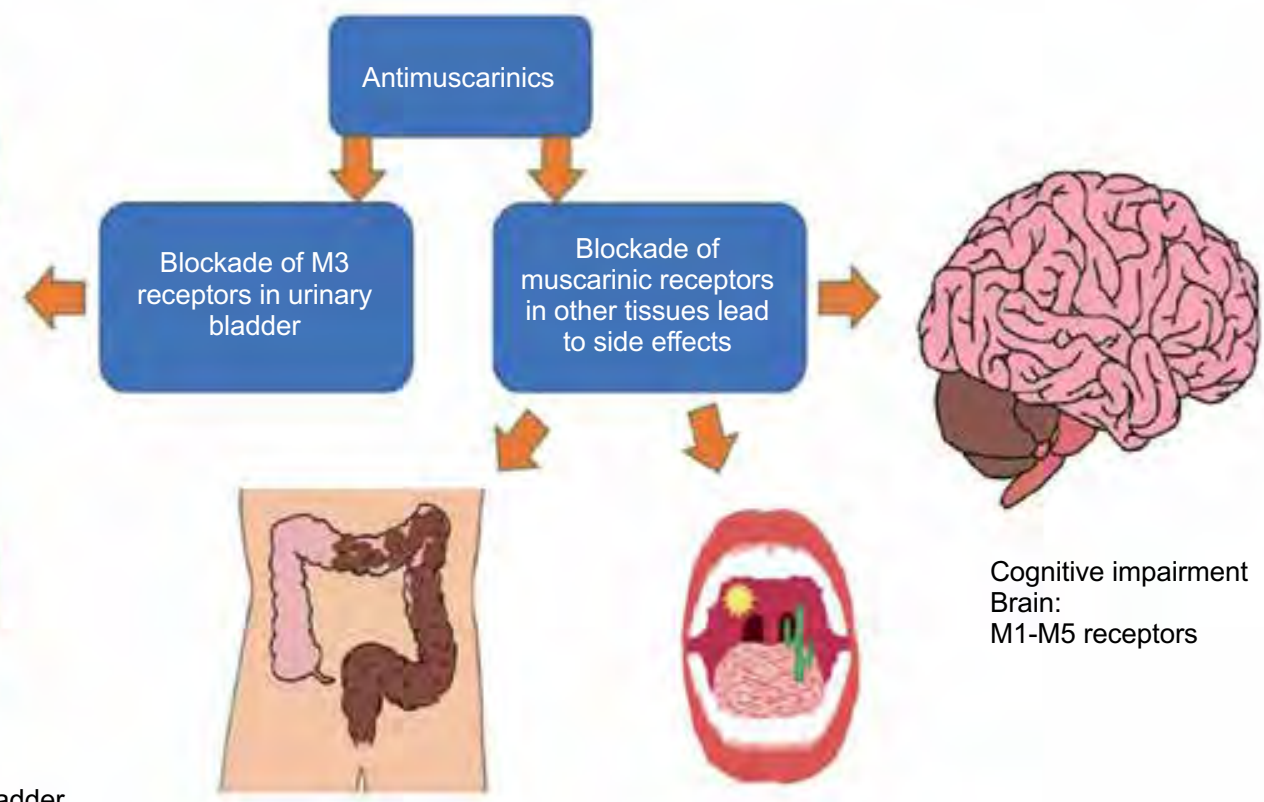

Cognitive impairment Brain:

M1-M5 receptors

Dry mouth

Salivary glands:

$\mathrm{M} 1$ and $\mathrm{M} 3$ receptors

FIG 3. Connection between the expression and distribution of muscarinic acetylcholine receptors and the tolerability of antimuscarinics 


\section{Beta-3 adrenoceptor agonist}

Beta-3 agonist is a new class of pharmacological treatment used to relieve storage symptoms (urgency, urinary frequency, and urge urinary incontinence) associated with overactive bladder. It acts by binding to the $\beta 3$ adrenergic receptors on the bladder smooth muscle causing bladder relaxation during the storage phase. Mirabegron is currently the only approved $\beta 3$ agonist for treatment of overactive bladder.

ln a phase III clinical trial, mirabegron $50 \mathrm{mg}$ daily resulted in a $50 \%$ reduction in the number of urgency episodes per 24 hours and a $128 \%$ increase in the mean volume voided per micturition compared with placebo. ${ }^{44}$ Unlike antimuscarinics, it has better tolerability with less dry mouth. In the study, mirabegron's incidence of dry mouth was similar to that of placebo. ${ }^{45}$

Mirabegron has no influence on bladder contraction during the voiding phase. In the clinical trial, the incidence rate of acute urinary retention was the lowest in mirabegron-treated patients compared with the tolterodine and placebo groups $\left(0.1 \%, 0.6 \%\right.$, and $0.2 \%$, respectively) ${ }^{44}$ The same trial showed that mirabegron did not increase intraocular pressure, and it is therefore not contra-indicated in patients with glaucoma.

Regarding cardiovascular safety, the review and real-world data on mirabegron did not show any increased risk compared with conventional antimuscarinics or in those with coexisting cardiovascular disease. ${ }^{46,47}$ The European Association of Urology guideline recommends $\beta 3$ agonist as a first-line medication for men with moderateto-severe LUTS who have predominantly bladder storage symptoms. ${ }^{48}$

Beta-3 agonist can be considered when antimuscarinic adverse effects and high anticholinergic burden are concerns, especially in elderly adults with multiple co-morbidities and cognitive impairment. Several studies have shown that mirabegron is safe and effective in older patients. ${ }^{49-51}$

The recommended dosage of mirabegron is $50 \mathrm{mg}$ daily. For patients with renal impairment (estimated glomerular filtration rate $15-29 \mathrm{~mL} / \mathrm{min} /$ $1.73 \mathrm{~m}^{2}$ ), Child-Pugh class B liver impairment, and those aged $\geq 80$ years with multiple co-morbidities, $25 \mathrm{mg}$ daily should be considered. Mirabegron is not recommended in patients with poorly controlled hypertension (systolic blood pressure $>180 \mathrm{~mm} \mathrm{Hg}$ or diastolic blood pressure $>110 \mathrm{~mm} \mathrm{Hg}$ ), severe renal impairment (estimated glomerular filtration rate $<15 \mathrm{~mL} / \mathrm{min} / 1.73 \mathrm{~m}^{2}$ ), or Child-Pugh class $\mathrm{C}$ liver impairment. The most common adverse effects reported were hypertension, nasopharyngitis, and headache but the overall adverse event rates were similar to those with placebo. ${ }^{52}$

\section{$5 \alpha$-reductase inhibitors}

$5 \alpha$-reductase is responsible for conversion of testosterone to dihydrotestosterone, which has an important role in prostate growth and the development of $\mathrm{BPH} .{ }^{53}$ There are two isoforms of $5 \alpha$-reductase: type 1 -the predominant enzyme in extraprostatic tissue such as skin and liver; and type 2 -the predominant enzyme in prostate (>90\%), which is critical to development of $\mathrm{BPH}$.

The 5ARi drugs inhibit conversion of testosterone to dihydrotestosterone, inducing apoptosis and atrophy of prostatic epithelial cells. ${ }^{54}$ It results in reduction of prostate volume and hence relief of bladder outflow obstruction. There are two types of 5ARi: finasteride, which acts only on type $25 \alpha$-reductase, and dutasteride, which acts on both types. Meta-analysis has shown no differences in efficacy or safety among these two drugs. ${ }^{55,56}$ There are a few registered 5ARi drugs: Proscar (finasteride $5 \mathrm{mg}$ ), Avodart (dutasteride $0.5 \mathrm{mg}$ ), and Duodart (combination of dutasteride $0.5 \mathrm{mg}$ and tamsulosin $0.4 \mathrm{mg})$.

Long-term 5ARi treatment in patients with moderate to severe LUTS and prostate volume $>40 \mathrm{cc}$ has been shown to reduce the symptoms score, risk of urinary retention, and risk of $\mathrm{BPH}$ related surgery. In a landmark study, patients taking finasteride had improvement in symptoms and uroflow, their prostate size reduced by $20 \%$, their risk of acute urinary retention reduced by $57 \%$, and their risk of BPH-related surgery reduced by $55 \%$ compared with placebo after 4 years of treatment. ${ }^{56}$

There are some practical tips for prescribing 5ARi. First, the patient should have an enlarged prostate $>40 \mathrm{cc}$ on ultrasound imaging. If ultrasound is not readily available, it is acceptable to start $5 \mathrm{ARi}$ treatment when the prostate size is greater than two finger breadths on DRE. Second, it is important to inform the patient that $5 \mathrm{ARi}$ have a slow onset of action (3-6 months), as time is required for prostate volume reduction. Continuous long-term treatment should be expected. Third, the effects of 5 ARis on PSA levels should be explained to patients. The PSA level is expected to be reduced by $50 \%$ after 6 to 12 months of treatment, ${ }^{56}$ and therefore, good drug compliance is required for proper interpretation of the PSA level in prostate cancer screening. A persistent PSA rise from the nadir in a patient on long-term 5ARi treatment is an indicator for prostate biopsy, and urological referral should be considered. ${ }^{57}$ Finally, although some studies have suggested a higher incidence of high-grade prostate cancer in patients taking long-term 5ARi, no causal relationship has been proven, and there is no difference in longterm survival. ${ }^{58}$ The common adverse effects are sexual dysfunction, such as decreased libido, erectile dysfunction, and ejaculatory problems in around $4 \%$ 
to $8 \%$ and breast enlargement and tenderness in $1 \%$ of patients..$^{56}$

\section{Conclusion}

Male LUTS is a common presentation to primary care practitioners. Focused history and physical examination are essential to differentiate $\mathrm{BPH}$ from other causes of male LUTS and to guide its management. Patients with minimal symptoms can be managed conservatively, and pharmacological treatments can be considered if symptoms are bothersome. For patients with symptoms refractory to pharmacological treatments or who have complications (eg, urinary retention, obstructive uropathy), surgical intervention can be performed after assessment by urologists. With an ageing population, geriatricians are adopting an increasing role in the management of male patients with LUTS in the era of multiple co-morbidities and polypharmacy, as these patients are at higher risk of adverse effects from pharmacological treatments and are not optimal for surgical intervention. A consensus has been reached by the HKGS and HKUA regarding the diagnosis, evaluation, management, and referral mechanism for LUTS in the primary care setting. With collaboration between primary care practitioners, geriatricians and urologists, we hope that more holistic care can be provided to male patients with LUTS in Hong Kong.

\section{Author contributions}

All authors contributed to the concept or design of the study, acquisition of the data, analysis or interpretation of the data, drafting of the manuscript, and critical revision of the manuscript for important intellectual content. All authors had full access to the data, contributed to the study, approved the final version for publication, and take responsibility for its accuracy and integrity.

\section{Conflicts of interest}

All authors have disclosed no conflicts of interest.

\section{Acknowledgements}

We thank Dr $\mathrm{CH}$ Cheng for drawing the images in Figures 2 and 3; and Dr CW Man for his assistance in editing the manuscript.

\section{Funding/support}

This research received no specific grant from any funding agency in the public, commercial, or not-for-profit sectors.

\section{References}

1. United Nations Development Programme. Human Development Report 2019. Beyond income, beyond averages, beyond today: inequalities in human development in the 21st century. 2019. Available from: http://hdr. undp.org/en/content/human-development-report-2019. Accessed 7 Jul 2020.
2. Berry SJ, Coffey DS, Walsh PC, Ewing LL. The development of human benign prostatic hyperplasia with age. J Urol 1984;132:474-9.

3. van den Akker M, Buntinx F, Metsemakers JF, Roos S, Knottnerus JA. Multimorbidity in general practice: prevalence, incidence, and determinants of co-occurring chronic and recurrent diseases. J Clin Epidemiol 1998;51:367-75.

4. Ball AJ, Feneley RC, Abrams PH. The natural history of untreated "prostatism". Br J Urol 1981;53:613-6.

5. Gravas S, Cornu JN, Gacci M, et al. EAU Guidelines on management of non-neurogenic male LUTS. Arnhem, The Netherlands: EAU Guidelines Office; 2020.

6. Brown CT, Yap T, Cromwell DA, et al. Self management for men with lower urinary tract symptoms: randomised controlled trial. BMJ 2007;334:25.

7. Djavan B, Marberger M. A meta-analysis on the efficacy and tolerability of alpha1-adrenoceptor antagonists in patients with lower urinary tract symptoms suggestive of benign prostatic obstruction. Eur Urol 1999;36:1-13.

8. Fried LP, Tangen CM, Walston J, et al. Frailty in older adults: evidence for a phenotype. J Gerontol A Biol Sci Med Sci 2001;56:M146-56.

9. Tjia J, Velten SJ, Parsons C, Valluri S, Briesacher BA. Studies to reduce unnecessary medication use in frail older adults: a systematic review. Drugs Aging 2013;30:285-307.

10. Michel MC, Vrydag W. Alpha1-, alpha2- and betaadrenoceptors in the urinary bladder, urethra and prostate. Br J Pharmacol 2006;147 Suppl 2:S88-119.

11. AUA Practice Guidelines Committee. AUA guideline on management of benign prostatic hyperplasia (2003). Chapter 1: Diagnosis and treatment recommendations. J Urol 2003;170:530-47.

12. Welk B, McArthur E, Fraser LA, et al. The risk of fall and fracture with the initiation of a prostate-selective $\alpha$ antagonist: a population based cohort study. BMJ 2015;351:h5398.

13. Djavan B, Chapple C, Milani S, Marberger M. State of the art on the efficacy and tolerability of alpha1-adrenoceptor antagonists in patients with lower urinary tract symptoms suggestive of benign prostatic hyperplasia. Urology 2004:64:1081-8.

14. Morgia G. Does the use of silodosin to treat benign prostatic hyperplasia really offer something new? Eur Urol 2011;59:353-5.

15. Chapple CR, Montorsi F, Tammela TL, et al. Silodosin therapy for lower urinary tract symptoms in men with suspected benign prostatic hyperplasia: results of an international, randomized, double-blind, placebo- and active-controlled clinical trial performed in Europe. Eur Urol 2011;59:342-52.

16. Storr-Paulsen A, Nørregaard JC, Børme KK, Larsen AB, Thulesen J. Intraoperative floppy iris syndrome (IFIS): a practical approach to medical and surgical considerations in cataract extractions. Acta Ophthalmol 2009;87:704-8.

17. Gacci M, Ficarra V, Sebastianelli A, et al. Impact of medical treatments for male lower urinary tract symptoms due to benign prostatic hyperplasia on ejaculatory function: a systematic review and meta-analysis. J Sex Med 2014;11:1554-66.

18. United States Department of Veterans Affairs. Pharmacy Benefits Management Services, Medical Advisory Panel, VISN Pharmacist Executives. Alfuzosin, silodosin, 
tamsulosin/clinically uroselective alpha1-adrenergic blockers: recommendations for use. 2010. Available from: https://www.pbm.va.gov/PBM/clinicalguidance/ clinicalrecommendations/Alpha_Blockers_(Clinically_ Uroselective_Alfuzosin_Silodosin_Tamsulosin)_Clinical_ Recommendations.pdf. Accessed 27 Nov 2019.

19. Boyle P, Napalkov P. The epidemiology of benign prostatic hyperplasia and observations on concomitant hypertension. Scand J Urol Nephrol Suppl 1995;168:7-12.

20. ALLHAT Collaborative Research Group [editorial]. Major cardiovascular events in hypertensive patients randomized to doxazosin vs chlorthalidone: the antihypertensive and lipid-lowering treatment to prevent heart attack trial (ALLHAT). JAMA 2000;283:1967-75.

21. Dahlöf B, Sever PS, Poulter NR, et al. Prevention of cardiovascular events with an antihypertensive regimen of amlodipine adding perindopril as required versus atenolol adding bendroflumethiazide as required, in the AngloScandinavian Cardiac Outcomes Trial-Blood Pressure Lowering Arm (ASCOT-BPLA): a multicentre randomised controlled trial. Lancet 2005;366:895-906.

22. Lowe FC, Olson PJ, Padley RJ. Effects of terazosin therapy on blood pressure in men with benign prostatic hyperplasia concurrently treated with other antihypertensive medications. Urology 1999;54:81-5.

23. Chung BH, Hong SJ. Long-term follow-up study to evaluate the efficacy and safety of the doxazosin gastrointestinal therapeutic system in patients with benign prostatic hyperplasia with or without concomitant hypertension. BJU Int 2006;97:90-5.

24. Lee SH, Park KK, Mah SY, Chung BH. Effects of $\alpha$-blocker 'add on' treatment on blood pressure in symptomatic $\mathrm{BPH}$ with or without concomitant hypertension. Prostate Cancer Prostatic Dis 2010;13:333-7.

25. Black HR, Keck M, Meredith P, Bullen K, Quinn S, Koren A. Controlled-release doxazosin as combination therapy in hypertension: the GATES study. J Clin Hypertens (Greenwich) 2006;8:159-66.

26. de Alvaro F, Hernández-Presa MA, ASOCIA Study. Effect of doxazosin gastrointestinal therapeutic system on patients with uncontrolled hypertension: the ASOCIA Study. J Cardiovasc Pharmacol 2006;47:271-6.

27. Fleg JL, Evans GW, Margolis KL, et al. Orthostatic hypotension in the ACCORD (Action to Control Cardiovascular Risk in Diabetes) blood pressure trial: prevalence, incidence, and prognostic significance. Hypertension 2016;68:888-95.

28. SPRINT Research Group; Wright JT Jr, Williamson JD, et al. A randomized trial of intensive versus standard bloodpressure control. N Engl J Med 2015;373:2103-16.

29. Hiremath S, Ruzicka M, Petrcich W, et al. Alpha-blocker use and the risk of hypotension and hypotension-related clinical events in women of advanced age. Hypertension 2019;74:645-51.

30. James PA, Oparil S, Carter BL, et al. 2014 evidence-based guideline for the management of high blood pressure in adults: report from the panel members appointed to the Eighth Joint National Committee (JNC 8). JAMA 2014;311:507-20.

31. Williams B, Mancia G, Spiering W, et al. 2018 ESC/ESH Guidelines for the management of arterial hypertension: The Task Force for the management of arterial hypertension of the European Society of Cardiology and the European Society of Hypertension: The Task Force for the management of arterial hypertension of the European Society of Cardiology and the European Society of Hypertension. J Hypertens 2018;36:1953-2041.

32. Whelton PK, Carey RM, Aronow WS, et al. 2017 ACC/ AHA/AAPA/ABC/ACPM/AGS/APhA/ASH/ASPC/ NMA/PCNA Guideline for the Prevention, Detection, Evaluation, and Management of High Blood Pressure in Adults: A Report of the American College of Cardiology/ American Heart Association Task Force on Clinical Practice Guidelines. Hypertension 2018;71:e13-e115.

33. Leung AA, Daskalopoulou SS, Dasgupta K, et al. Hypertension Canada's 2017 Guidelines for Diagnosis, Risk Assessment, Prevention, and Treatment of Hypertension in Adults. Can J Cardiol 2017;33:557-76.

34. Finney SM, Andersson KE, Gillespie JI, Stewart LH. Antimuscarinic drugs in detrusor overactivity and the overactive bladder syndrome: motor or sensory actions? BJU Int 2006;98:503-7.

35. Shamliyan T, Wyman JF, Ramakrishnan R, Sainfort F, Kane RL. Benefits and harms of pharmacologic treatment for urinary incontinence in women: a systematic review. Ann Intern Med 2012;156:861-74

36. Reynolds WS, McPheeters M, Blume J, et al. Comparative effectiveness of anticholinergic therapy for overactive bladder in women: a systematic review and meta-analysis. Obstet Gynecol 2015;125:1423-32.

37. Qaseem A, Dallas P, Forciea MA, et al. Nonsurgical management of urinary incontinence in women: a clinical practice guideline from the American College of Physicians. Ann Intern Med 2014;161:429-40.

38. Brostrøm S, Hallas J. Persistence of antimuscarinic drug use. Eur J Clin Pharmacol. 2009;65:309-14.

39. Coupland CA, Hill T, Dening T, Morriss R, Moore M, Hippisley-Cox J. Anticholinergic drug exposure and the risk of dementia: a nested case-control study. JAMA Intern Med 2019;179:1084-93.

40. Fox C, Richardson K, Maidment ID, et al. Anticholinergic medication use and cognitive impairment in the older population: the medical research council cognitive function and ageing study. J Am Geriatr Soc 2011;59:1477-83.

41. Durán CE, Azermai M, Vander Stichele RH. Systematic review of anticholinergic risk scales in older adults. Eur J Clin Pharmacol 2013;69:1485-96.

42. Salahudeen MS, Hilmer SN, Nishtala PS. Comparison of anticholinergic risk scales and associations with adverse health outcomes in older people. J Am Geriatr Soc 2015;63:85-90.

43. American Geriatrics Society 2015 Beers Criteria Update Expert Panel. American Geriatrics Society 2015 updated Beers criteria for potentially inappropriate medication use in older adults. J Am Geriatr Soc 2015;63:2227-46.

44. Chapple CR, Cardozo L, Nitti VW, Siddiqui E, Michel MC. Mirabegron in overactive bladder: a review of efficacy, safety, and tolerability. Neurourol Urodyn 2014;33:17-30.

45. Khullar V, Amarenco G, Angulo JC, et al. Efficacy and tolerability of mirabegron, a $\beta(3)$-adrenoceptor agonist, in patients with overactive bladder: results from a randomised European-Australian phase 3 trial. Eur Urol 2013;63:28395.

46. Rosa GM, Ferrero S, Nitti VW, Wagg A, Saleem T, Chapple CR. Cardiovascular safety of $\beta 3$-adrenoceptor agonists for the treatment of patients with overactive 
bladder syndrome. Eur Urol 2016;69:311-23.

47. Katoh T, Kuwamoto K, Kato D, Kuroishi K. Real-world cardiovascular assessment of mirabegron treatment in patients with overactive bladder and concomitant cardiovascular disease: results of a Japanese post-marketing study. Int J Urol 2016;23:1009-15.

48. Burkhard FC, Bosch JL, Cruz F, et al. EAU Guidelines on urinary incontinence in adults. Arnhem, The Netherlands: EAU Guidelines Office; 2016.

49. Wagg A, Staskin D, Engel E, Herschorn S, Kristy RM, Schermer CR. Efficacy, safety, and tolerability of mirabegron in patients aged $\geq 65 \mathrm{yr}$ with overactive bladder wet: a phase IV, double-blind, randomised, placebo-controlled study (PILLAR). Eur Urol 2020;77:211-20.

50. Makhani A, Thake M, Gibson W. Mirabegron in the treatment of overactive bladder: safety and efficacy in the very elderly patient. Clin Interv Aging 2020;15:575-81.

51. Lee YK, Kuo HC. Safety and therapeutic efficacy of mirabegron $25 \mathrm{mg}$ in older patients with overactive bladder and multiple comorbidities. Geriatr Gerontol Int 2018;18:1330-3.

52. Tubaro A, Batista JE, Nitti VW, et al. Efficacy and safety of daily mirabegron $50 \mathrm{mg}$ in male patients with overactive bladder: a critical analysis of five phase III studies. Ther
Adv Urol 2017;9:137-54.

53. Carson C 3rd, Rittmaster R. The role of dihydrotestosterone in benign prostatic hyperplasia. Urology 2003;61(4 Suppl 1):2-7.

54. Rittmaster RS, Norman RW, Thomas LN, Rowden G. Evidence for atrophy and apoptosis in the prostates of men given finasteride. J Clin Endocrinol Metab 1996;81:814-9.

55. Jun JE, Kinkade A, Tung AC, Tejani AM. $5 \alpha$-reductase inhibitors for treatment of benign prostatic hyperplasia: a systematic review and meta-analysis. Can J Hosp Pharm 2017;70:113-9.

56. Roehrborn CG, Boyle P, Bergner D, et al. Serum prostatespecific antigen and prostate volume predict long-term changes in symptoms and flow rate: results of a four-year, randomized trial comparing finasteride versus placebo. PLESS Study Group. Urology 1999;54:662-9.

57. Marks LS, Andriole GL, Fitzpatrick JM, Schulman CC, Roehrborn CG. The interpretation of serum prostate specific antigen in men receiving 5alpha-reductase inhibitors: a review and clinical recommendations. J Urol 2006;176:868-74.

58. Thompson IM Jr, Goodman PJ, Tangen CM, et al. Longterm survival of participants in the prostate cancer prevention trial. N Engl J Med 2013;369:603-10. 
APPENDIX. International Prostate Symptoms Score (Hong Kong Chinese Version 2)

International Prostate Symptoms Score (Hong Kong Chinese Version 2)

國绦前列腺症狀評分表(中文香港版 2)

姓名:

日期：

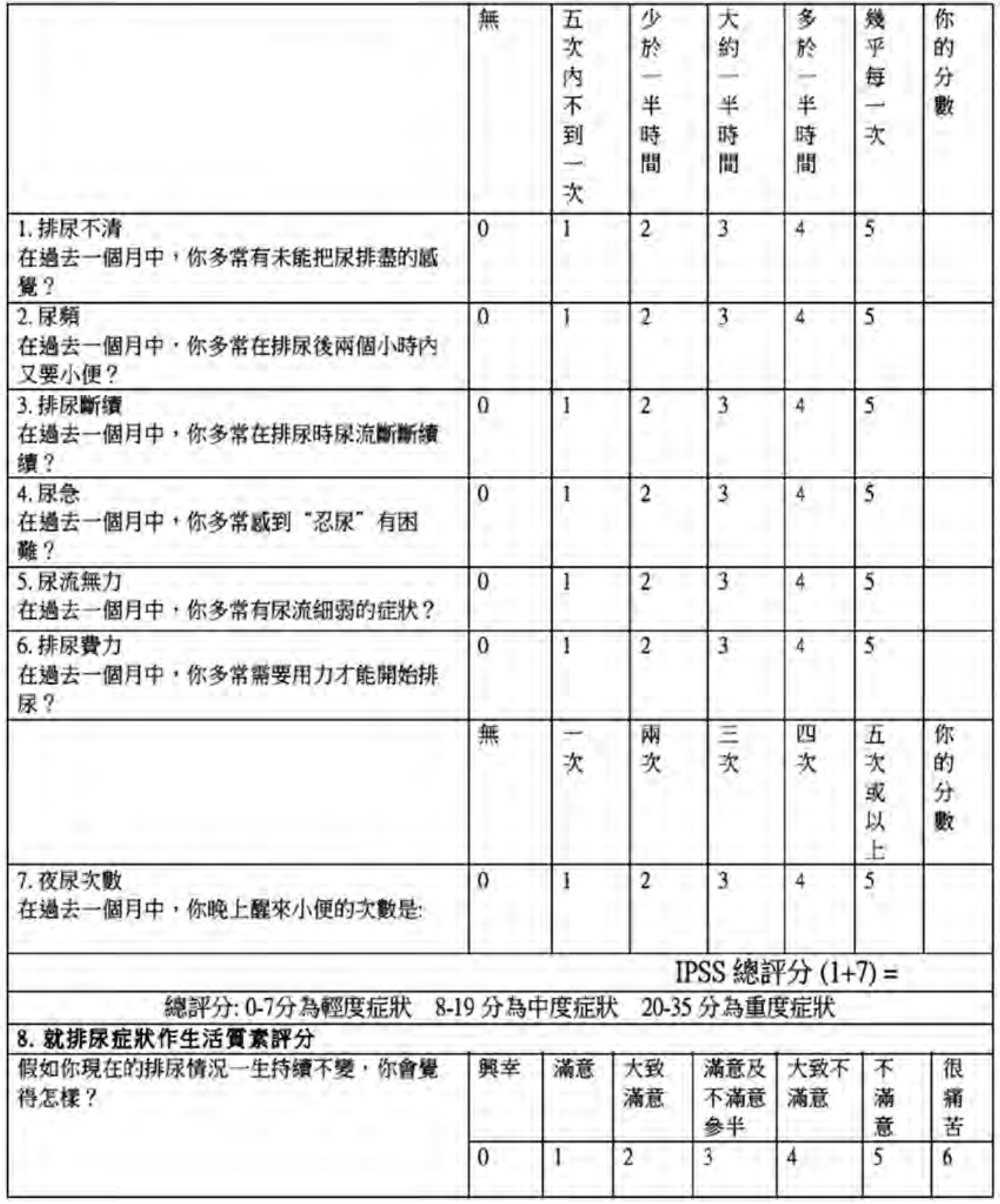

